\title{
Mullite in a buchite from Asama volcano and its sub-micrometric core-rim texture with sillimanite
}

\author{
Yohei IgAmi, Akira MiYAKe and Norimasa SHIMOBAYASHI \\ Department of Geology and Mineralogy, Graduate School of Science, Kyoto University, Kyoto 606-8502, Japan
}

\begin{abstract}
We report the discovery of mullite coexisting with sillimanite in a fused pelitic fragment, so-called buchite from Asama volcano, Japan. TEM observation revealed a core-rim texture in the examined fibrous minerals: cores are mullite with characteristic glass inclusions, and rims are sillimanite with abundant anti-phase boundaries. These two phases have common crystal axis directions and coherent boundaries, and thus have eluded accurate identification by previous workers using other analytical methods, e.g., optical microscopy, electron microprobe analysis, or XRD experiments. This sub-micrometric core-rim texture can explain inconsistencies among previous analytical results on the same fibrous mineral from Asama. We show that mullite formed from sillimanite with incongruent melting at high temperature, and, upon slight cooling, the outer parts of mullite grains reacted with the surrounding melt to retrogressively form sillimanite rims with abundant anti-phase boundaries. This texture indicates a compositional gap between sillimanite $\left(\mathrm{Al}_{2} \mathrm{SiO}_{5}\right)$ and $3: 2$ mullite $\left(3 \mathrm{Al}_{2} \mathrm{O}_{3} \cdot 2 \mathrm{SiO}_{2}\right)$ and is evidence against a low-pressure complete solid solution between the two phases.
\end{abstract}

Keywords: Mullite, Sillimanite, Transmission electron microscope, Asama volcano

\section{INTRODUCTION}

The $\mathrm{Al}_{2} \mathrm{SiO}_{5}$ polymorphs are valuable indicators of the pressure and temperature conditions experienced by metamorphic rocks. However, Bowen and Greig (1924) pointed out that the stable phase in the $\mathrm{Al}_{2} \mathrm{O}_{3}-\mathrm{SiO}_{2}$ system at certain high temperatures is more $\mathrm{Al}$-rich than $\mathrm{Al}_{2}$ $\mathrm{SiO}_{5}$. It was later concluded that this $\mathrm{Al}$-rich phase forms a solid solution, generally expressed as $\mathrm{Al}_{2}\left(\mathrm{Al}_{2+2 x} \mathrm{Si}_{2-2 x}\right)$ $\mathrm{O}_{10-x}$, where $x=0.17-0.59$ (Cameron, 1977). Bowen and Greig (1924) discovered the Al-rich compound $\left(3 \mathrm{Al}_{2} \mathrm{O}_{3}\right.$. $2 \mathrm{SiO}_{2}$ ) in natural rocks from the Isle of Mull, and mullite is now one of the most frequently used and important mineral phases in the ceramic industry.

The crystal structure of mullite [space group: Pbam (No. 55), cell parameters: $a=7.54336, b=7.69176, c=$ $2.88402 \AA$; Balzar and Ledbetter, 1993] consists of $\mathrm{AlO}_{6}$ octahedral chains linked to $\mathrm{SiO}_{4} / \mathrm{AlO}_{4}$ tetrahedral double chains parallel to the $c$-axis. This basic framework is the same as that of sillimanite [space group: Pbnm (No. 62), cell parameters: $a=7.4883, b=7.6808, c=5.7774 \AA$; Winter and Ghose, 1979], one of the $\mathrm{Al}_{2} \mathrm{SiO}_{5}$ polymorphs.

doi:10.2465/jmps. 180201

Y. Igami, y-igami@kueps.kyoto-u.ac.jp Corresponding author
Thus, the cell parameters and optical properties of mullite are closely related to those of sillimanite, and natural occurrences of mullite may have been overlooked, especially given the belief that mullite occurs rarely in nature because its formation requires high temperature and low pressure.

Asama volcano is an andesitic volcano in central Japan, one of the most active volcanoes in Japan and is the only reported locality that naturally produces mullitelike minerals in Japan. Aramaki (1961) found fibrous aluminosilicates in pelitic xenoliths from Asama and showed that they are slightly enriched in $\mathrm{Al}$ than sillimanite but less so than normal $3: 2$ mullite $\left(3 \mathrm{Al}_{2} \mathrm{O}_{3}\right.$. $2 \mathrm{SiO}_{2}$ ). Moreover, his X-ray diffraction (XRD) results provided a basic-cell size intermediate between those of sillimanite and 3:2 mullite. He concluded that this mineral is Al-rich sillimanite with intermediate composition between those of sillimanite and mullite, and this aluminosilicate from Asama has been treated as a rare and valuable example supporting the existence of the complete solid solution between the two phases. However, Cameron and Ashworth (1972) conducted electron microprobe (EMP) analysis of the Asama fibrous aluminosilicate and reported it to be normal Fe-bearing sillimanite with only 4 atomic $\%$ of the Si replaced by Al. Furthermore, Matsu- 

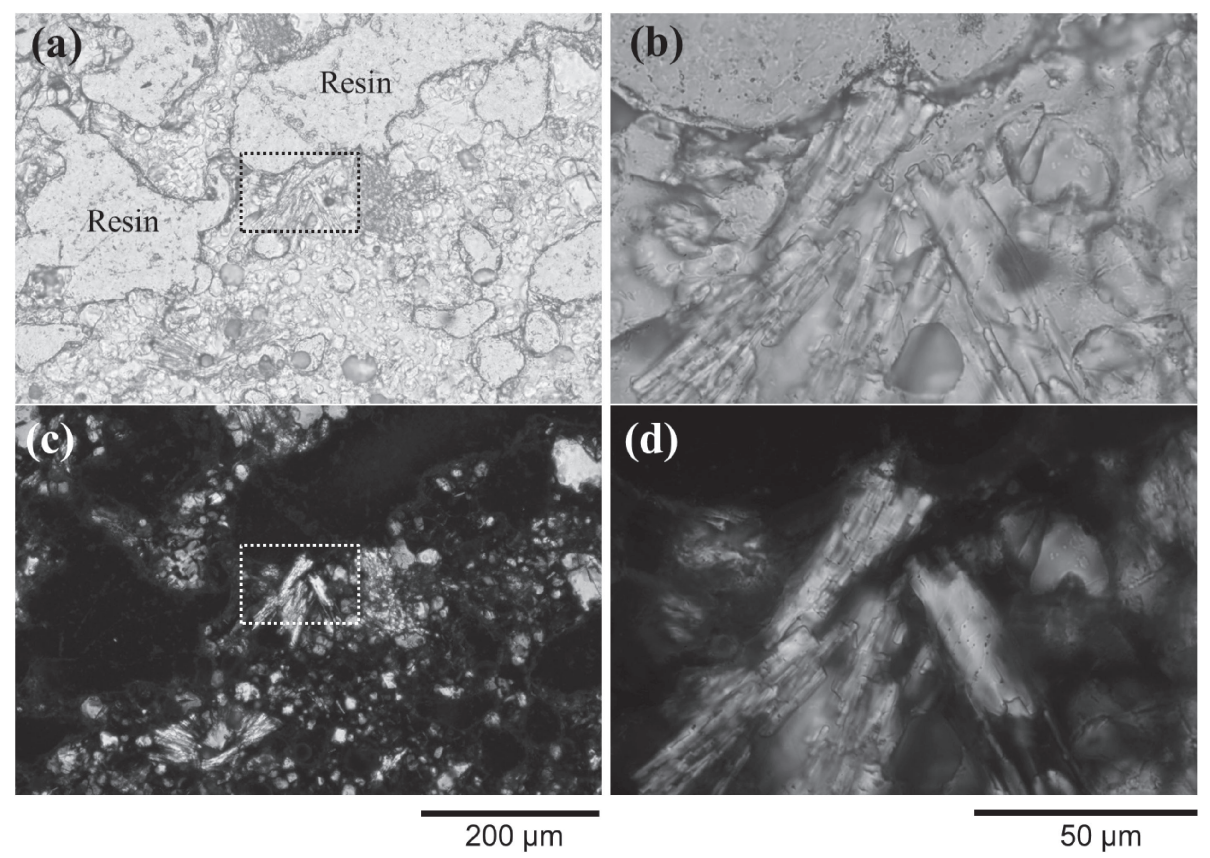

Figure 1. Optical microscope images of fibrous aluminosilicates in the fragment from Asama volcano under plane-polarized (a) and (b). Cross-polarized light (c) and (d). (b) and (d) are enlarged from the dotted rectangle in (a) and (c), respectively. Color version is available online from https://doi.org/10. $2465 /$ jmps. 180201. bara et al. (1998) analyzed many points of fibrous aluminosilicates in fused pelitic rock (buchite) from Asama via EMP and reported the existence of 3:2 mullite, sillimanite, and siliceous mullite. They also showed that the chemical composition of siliceous mullite was spatially heterogeneous within a single crystal. Since then, no further studies of the fibrous aluminosilicate from Asama have been conducted, although its exact composition and crystal structure remains unclear.

In this study, we performed transmission electron microscope (TEM) analysis with energy dispersive X-ray spectrometry (EDS) to more accurately identify the mullite-like fibrous mineral phase from Asama. We use our results to discuss the cause of inconsistencies among previous studies.

\section{EXPERIMENTAL PROCEDURE}

\section{Sample description}

The sample is a white fragment, so-called buchite, collected at Asama volcano. This rock seems to have a similar appearance with the sample of Matsubara et al. (1998). Our sample contains fibrous minerals with appearance similar to sillimanite or mullite that are about $1 \times 10$ $\mu \mathrm{m}$ in size and aggregated (Fig. 1). This rock also contains plagioclase, cordierite, quartz, tridymite, and glass, consistent with previous reports (Aramaki, 1961; Matsubara et al., 1998). These samples are all likely to be same kind of rock, although Aramaki (1961) reported his sample as a pelitic xenolith and did not describe as a buchite. In fact, according to Grapes (2010), buchite also occurs as xenolith, and Aramaki (1961) described that the samples had been basement sedimentary rocks containing various minerals formed during pyrometamorphism and ejected from the Volcano. Figure 2 shows backscattered electron images of the fibrous minerals by scanning electron microscope (SEM; JEOL JSM-7001F), and indicates the points for EDS (Oxford X-Max ${ }^{\mathrm{N}}$ 150) chemical analysis. Chemical analyses were performed at $15 \mathrm{kV}$ with a $0.3 \mathrm{nA}$ beam current. The results are listed in Table 1, with $x$ value in $\left[\mathrm{Al}_{2}^{\mathrm{VI}}\left(\mathrm{Al}_{2+2 x} \mathrm{Si}_{2-2 x}\right)^{\mathrm{IV}} \mathrm{O}_{10-x}\right]$ and $(\mathrm{Al}+\mathrm{Fe}) / \mathrm{Si}$ ratio. The fibrous minerals seem to be aluminum silicates, but their $(\mathrm{Al}+\mathrm{Fe}) / \mathrm{Si}$ ratios vary between 1.5 and 3.0 and are frequently larger than 2.0 , whereas the $(\mathrm{Al}+\mathrm{Fe}) / \mathrm{Si}$ ratio of sillimanite is 2.0 and that of $3: 2$ mullite is 3.0. Some regions show $(\mathrm{Al}+\mathrm{Fe}) / \mathrm{Si}$ ratios less than 2.0. Normally, these compositions cannot construct the structure of sillimanite or mullite, and the $x$ value cannot be defined. These Si-rich regions tend to contain K.

\section{Sample preparation}

A section for TEM analysis was prepared from the relatively Al-rich fibrous mineral in Figure 2 using a focused ion beam (SEM+FIB; FEI Quanta 200 3DS). The section was cut perpendicular to the elongation of the crystal (as shown by white rectangle in Fig. 2). The analytical area $\left(\sim 15 \times 2 \mu \mathrm{m}^{2}\right)$ was coated with $\mathrm{Pt}$ and its surroundings were cut out to a depth of $\sim 5 \mu \mathrm{m}$ using a $\mathrm{Ga}^{+}$ion gun. Then the section was picked up from the sample and mounted on a TEM grid. The extracted section was thin- 

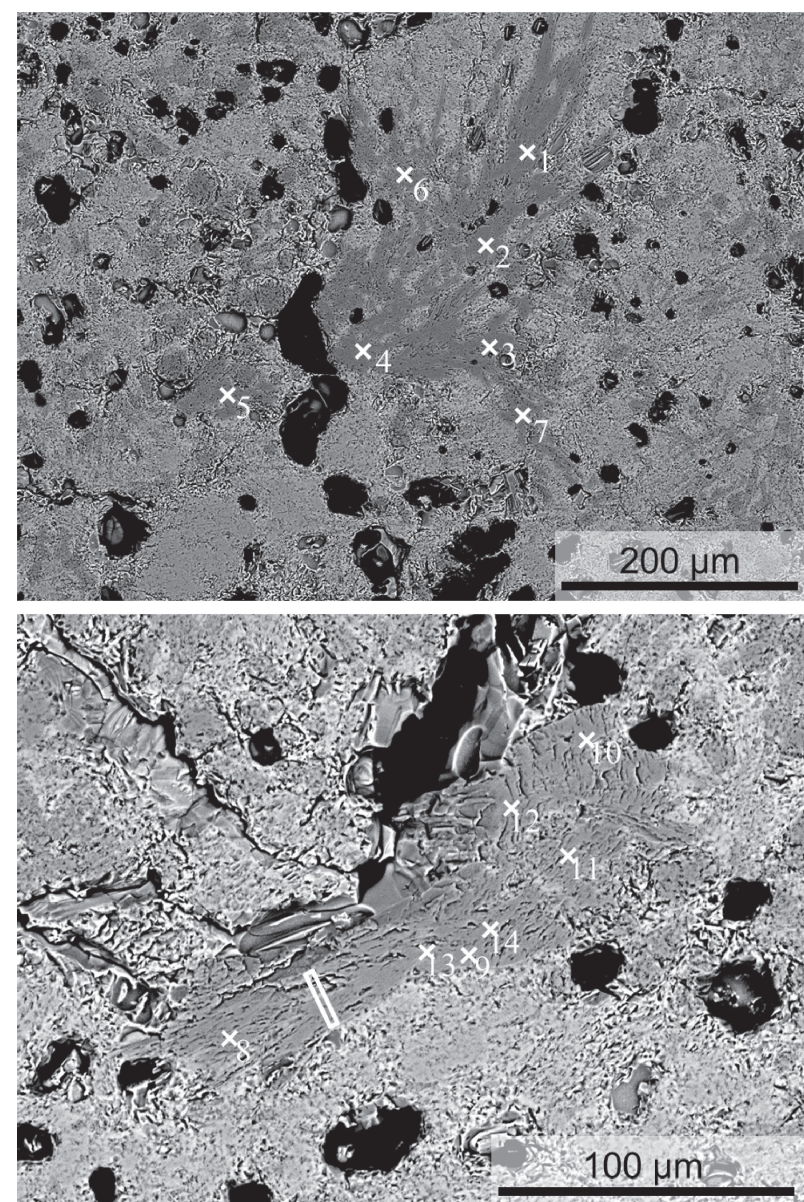

Figure 2. Backscattered electron images of aggregated fibrous aluminosilicates in the fragment from Asama volcano. Chemical analyses by SEM-EDS were performed at the positions shown by crosses (1-14; see Table 1). The TEM section was cut from the area shown by the white rectangle.

ned to a thickness of $\sim 150 \mathrm{~nm}$ using a $\mathrm{Ga}^{+}$ion beam at $30 \mathrm{kV}$ with beam currents of $0.1-3 \mathrm{nA}$. Finally, a $\mathrm{Ga}^{+}$ion beam at $5 \mathrm{kV}$ with a beam current of $48 \mathrm{pA}$ was used to remove amorphous surface layers.

\section{TEM/STEM-EDS analysis}

The section was observed with particular attention to the existence of mullite using a TEM (JEOL JEM-2100F) operated at $200 \mathrm{kV}$. TEM images were recorded using a CCD camera (Gatan Orius SC200D). Mullite was identified from its selected area electron diffraction (SAED) pattern based on its symmetrical difference with sillimanite. Mullite has a disordered distribution of $\mathrm{Si}$ and $\mathrm{Al}$ in tetrahedral sites, whereas sillimanite has an ordered distribution. Therefore, the $c$-axial length of mullite is half that of sillimanite, and the space group of mullite is Pbam whereas that of sillimanite is Pbnm. For simplification, we indexed all the SAED patterns based on the standard cell of sillimanite. In this case, $l=$ odd $(2 n+1)$ reflections are typical of sillimanite, but absent in mullite. Therefore, in addition to bright field (BF) imaging, the section was observed by dark field (DF) imaging taken from the $l=$ odd reflection of sillimanite.

Scanning TEM (STEM) imaging and X-ray mapping was performed for chemical analysis using an annular STEM detector and an EDS detector (JEOL JED2300T) equipped in the TEM. The acceptable angle of the STEM detector was set to approximately $50-150 \mathrm{mrad}$ to reflect the atomic numbers of the constituent elements (highangle annular dark-field STEM image: HAADF-STEM image). For precise quantification, the $\zeta$ factor method (Watanabe and Williams, 2006) was applied to X-ray intensities from regions of interest. Prior to elemental quantification, the $\zeta$ factors of our instrument were characterized for all elements of interest using a thin film of NIST SRM 2063a glass, according to protocols developed for the $\zeta$ factor method given by Watanabe and Williams (2006). X-ray absorption correction is promoted significantly with this method because the $\zeta$ factors are dependent only on the generated X-ray energy and accelerating voltage. The CCD camera was used to hold an accurate electron beam current. The $\zeta$-factor method requires all of the major element components contained in each material beforehand; therefore, the sample composition was qualitatively determined through elemental mapping prior to the quantitative analyses. Error values were calculated according to procedures given in Watanabe and Williams (2006).

\section{RESULTS}

\section{TEM and STEM observations}

Figure 3 shows TEM images and SAED patterns of a grain projected along the [012] direction. The SAED pattern shows that this grain has $h 21(l=1$ : odd) reflections of sillimanite (Fig. 3c). However, the dark field TEM (DF-TEM) image using the 221 ( $l=1$ :odd) reflection shows the clear core-rim texture (Fig. 3b). The dark appearance of the core and bright appearance of the rim indicate that the core is mullite, which does not show $l=$ odd reflections, whereas the rim is sillimanite. Moreover, the two minerals have common crystal axis directions and coherent lattice boundaries. Sillimanite in the rim displays abundant anti-phase boundaries (APBs) in DFTEM images taken from $l=$ odd reflections; APBs in sillimanite are not a general texture. The SAED pattern taken from the circle in Figure 3a clearly shows a glass halo (Fig. 3d); all regions with the same gray value in 
Table 1. Chemical compositions by SEM-EDS analyses

\begin{tabular}{lcccccccccccccc}
\hline & 1 & 2 & 3 & 4 & 5 & 6 & 7 & 8 & 9 & 10 & 11 & 12 & 13 & 14 \\
\hline $\mathrm{Na}_{2} \mathrm{O}$ & 0.38 & 0.53 & - & 0.17 & 0.07 & 0.15 & 0.12 & 0.22 & - & - & - & - & 0.18 & 0.11 \\
$\mathrm{Al}_{2} \mathrm{O}_{3}$ & 54.64 & 54.46 & 63.36 & 62.14 & 62.80 & 59.95 & 62.78 & 70.28 & 65.85 & 64.23 & 63.51 & 62.74 & 67.75 & 66.40 \\
$\mathrm{SiO}_{2}$ & 40.21 & 42.57 & 35.20 & 35.79 & 36.00 & 36.28 & 35.14 & 27.89 & 33.18 & 33.89 & 35.09 & 35.82 & 28.40 & 30.55 \\
$\mathrm{~K}_{2} \mathrm{O}$ & 0.62 & 0.87 & 0.06 & 0.18 & 0.07 & 0.23 & 0.12 & - & - & - & - & - & - & - \\
$\mathrm{TiO}_{2}$ & 0.14 & 0.14 & - & - & - & - & - & 0.13 & 0.15 & - & - & - & 0.21 & 0.18 \\
$\mathrm{~V}_{2} \mathrm{O}_{5}$ & - & - & - & - & - & - & - & - & - & - & - & 0.14 & - & - \\
$\mathrm{Fe}_{2} \mathrm{O}_{3}$ & 0.99 & 0.99 & 0.91 & 0.92 & 0.82 & 0.80 & 0.86 & 0.98 & 0.85 & 0.86 & 1.00 & 0.89 & 0.98 & 0.88 \\
$\mathrm{Total}$ & 96.96 & 99.56 & 99.54 & 99.20 & 99.76 & 97.41 & 99.01 & 99.50 & 100.02 & 98.98 & 99.59 & 99.60 & 97.51 & 98.11 \\
\hline $\mathrm{O}$ & 5 & 5 & 5 & 5 & 5 & 5 & 5 & 5 & 5 & 5 & 5 & 5 & 5 & 5 \\
$\mathrm{Na}$ & 0.02 & 0.03 & - & 0.01 & 0.00 & 0.01 & 0.01 & 0.01 & - & - & - & - & 0.01 & 0.01 \\
$\mathrm{Al}$ & 1.80 & 1.74 & 2.03 & 2.00 & 2.01 & 1.97 & 2.03 & 2.27 & 2.10 & 2.08 & 2.04 & 2.01 & 2.23 & 2.18 \\
$\mathrm{Si}$ & 1.12 & 1.16 & 0.96 & 0.98 & 0.98 & 1.01 & 0.96 & 0.77 & 0.90 & 0.93 & 0.96 & 0.97 & 0.79 & 0.85 \\
$\mathrm{~K}$ & 0.02 & 0.03 & 0.00 & 0.01 & 0.00 & 0.01 & 0.00 & - & - & - & - & - & - & - \\
$\mathrm{Ti}$ & 0.00 & 0.00 & - & - & - & - & - & 0.00 & 0.00 & - & - & - & 0.00 & 0.00 \\
$\mathrm{~V}$ & - & - & - & - & - & - & - & - & - & - & - & 0.00 & - & - \\
$\mathrm{Fe}$ & 0.02 & 0.02 & 0.02 & 0.02 & 0.02 & 0.02 & 0.02 & 0.02 & 0.02 & 0.02 & 0.02 & 0.02 & 0.02 & 0.02 \\
\hline$x$ value & - & - & 0.04 & 0.02 & 0.02 & - & 0.04 & 0.25 & 0.11 & 0.08 & 0.05 & 0.03 & 0.22 & 0.16 \\
$(\mathrm{Al}+\mathrm{Fe}) / \mathrm{Si}$ & 1.63 & 1.52 & 2.14 & 2.06 & 2.07 & 1.97 & 2.14 & 2.97 & 2.36 & 2.26 & 2.15 & 2.09 & 2.85 & 2.59 \\
\hline
\end{tabular}

The analyzed areas are indicated in Figure 2.
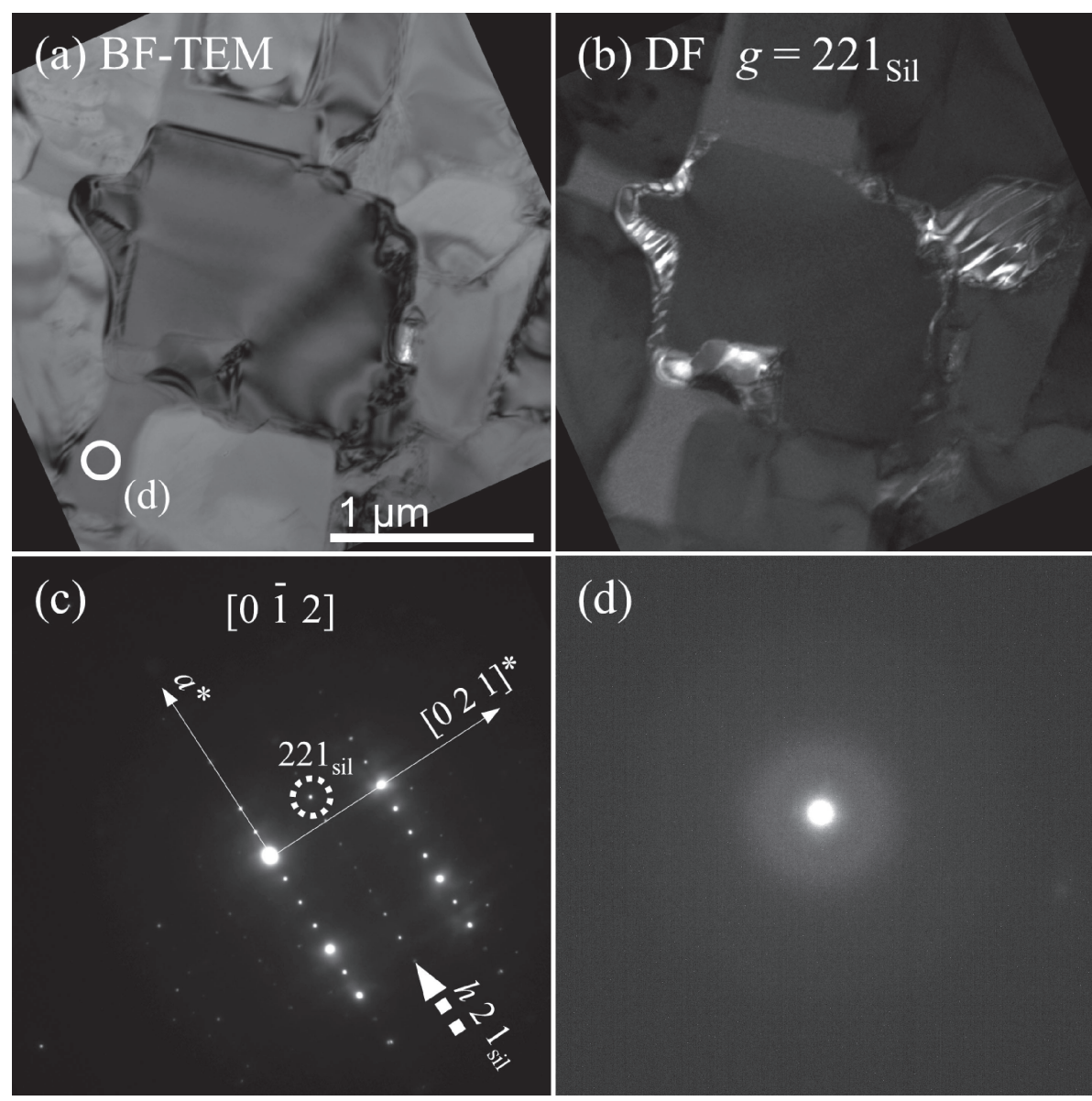

(d)
Figure 3. TEM images and diffraction patterns of the analyzed fibrous aluminosilicates: (a) BFTEM image, (b) DF-TEM image taken from the 221 reflection of sillimanite, (c) SAED pattern from the grain at the center of (a), and (d) SAED pattern from the region in the white circle in (a). 

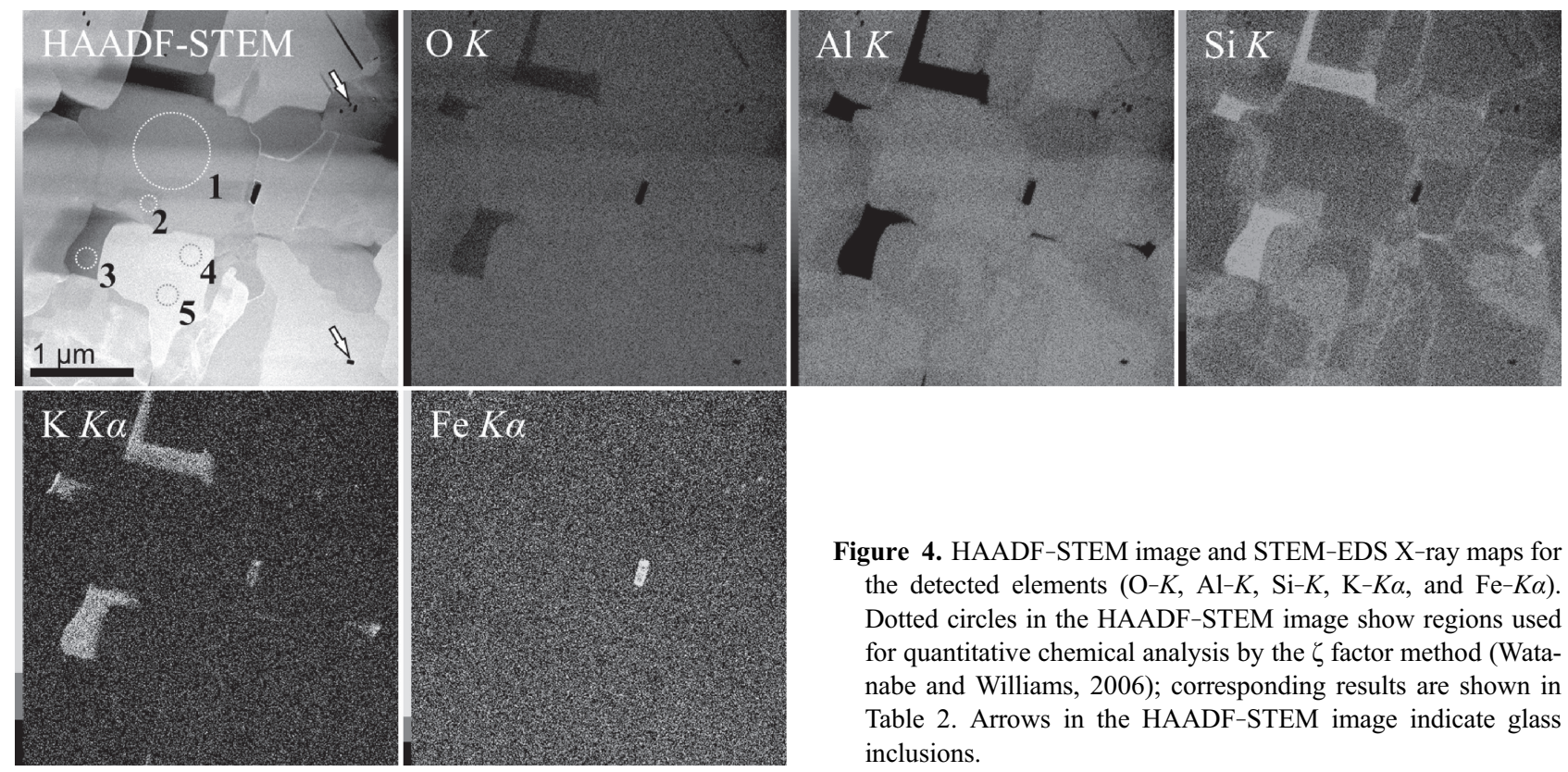

Figure 4. HAADF-STEM image and STEM-EDS X-ray maps for the detected elements $(\mathrm{O}-K, \mathrm{Al}-K, \mathrm{Si}-K, \mathrm{~K}-K \alpha$, and $\mathrm{Fe}-K \alpha)$. Dotted circles in the HAADF-STEM image show regions used for quantitative chemical analysis by the $\zeta$ factor method (Watanabe and Williams, 2006); corresponding results are shown in Table 2. Arrows in the HAADF-STEM image indicate glass inclusions.

Figure 3a are also glass phases. These glasses fill the gaps between grains of the fibrous minerals.

Figure 4 shows HAADF-STEM and STEM-EDS images (X-ray maps) of the same grain. The HAADFSTEM image and X-ray maps of $\mathrm{Al} K$ and Si $K$ show core-rim texture, and the core-rim boundary matches well with that of the DF-TEM image (Fig. 3b). The $\mathrm{Al}-K$ and $\mathrm{Si}-K$ STEM-EDS images indicate that the core is more $\mathrm{Al}$-rich and Si-poor than the rim. Almost all the grains in the scan area have similar core-rim textures. The interstitial glasses are significantly Si-rich.

Glass phases were also found as inclusions in mullite grains (Fig. 5). They are most clearly observed by projection from the $c$-axis of their host mullite, and they have characteristic shapes bounded by $\{110\}$ prismatic planes of mullite. High-resolution TEM images show that the inclusions have no lattice fringes (Fig. 5c), and the nano-beam electron diffraction pattern obtained from the center of an inclusion shows a glass halo and no diffraction spots from a crystalline phase (Fig. 5d). Such characteristic glass inclusions have been reported in mullite synthesized from sillimanite by annealing at high temperatures (e.g., Rahman et al., 2001).

\section{Quantitative compositional analysis by STEM-EDS}

Quantitative chemical compositions of analyzed areas (dotted circles in Fig. 4 and arrows in Fig. 5) were determined by the $\zeta$ factor method and are listed in Table 2. At the core (areas 1 and 4), $(\mathrm{Al}+\mathrm{Fe}) / \mathrm{Si}$ ratios is approximately 3 ( $x$ value is approximately 0.25 ), indicating that

the areas are 3:2 mullite, whereas at the rim (areas 2 and $5),(\mathrm{Al}+\mathrm{Fe}) / \mathrm{Si}$ ratios are approximately $2(x$ value is approximately 0 ), suggesting the areas to be sillimanite. The glass phases (areas 3, 6, and 7) show Al-poor chemical compositions, $(\mathrm{Al}+\mathrm{Fe}) / \mathrm{Si}<2$. However, interstitial glass is concentrated in $\mathrm{K}$ (area 3), but glass inclusions in mullite are $\mathrm{K}$ poor (areas 6 and 7). This difference is also displayed by $\mathrm{K}-K \alpha$ map in Figure 4 . In addition, X-ray intensities emitted from glass inclusions were sufficiently low due to their low density, which implies that they may contain a certain amount of water.

\section{DISCUSSION}

\section{Interpretation of previous inconsistencies}

We have shown that both mullite and sillimanite exist sub-microscopically in the buchite from Asama volcano. The two minerals show a core-rim texture with the common crystal axis directions and coherent boundaries. Because sillimanite and mullite have a similar optical property, it is very difficult to observe this texture under an optical microscopy; such grains would appear to be homogeneous single phase, i.e., sillimanite or mullite. We speculate that previous researchers analyzed similar grains with this core-rim texture but treated them as a single phase.

Previous researchers examined the chemical composition of fibrous aluminosilicates by means of various analytical methods, but those methods are unsuited to detect the core-rim texture. Wet chemical analysis gives no in- 

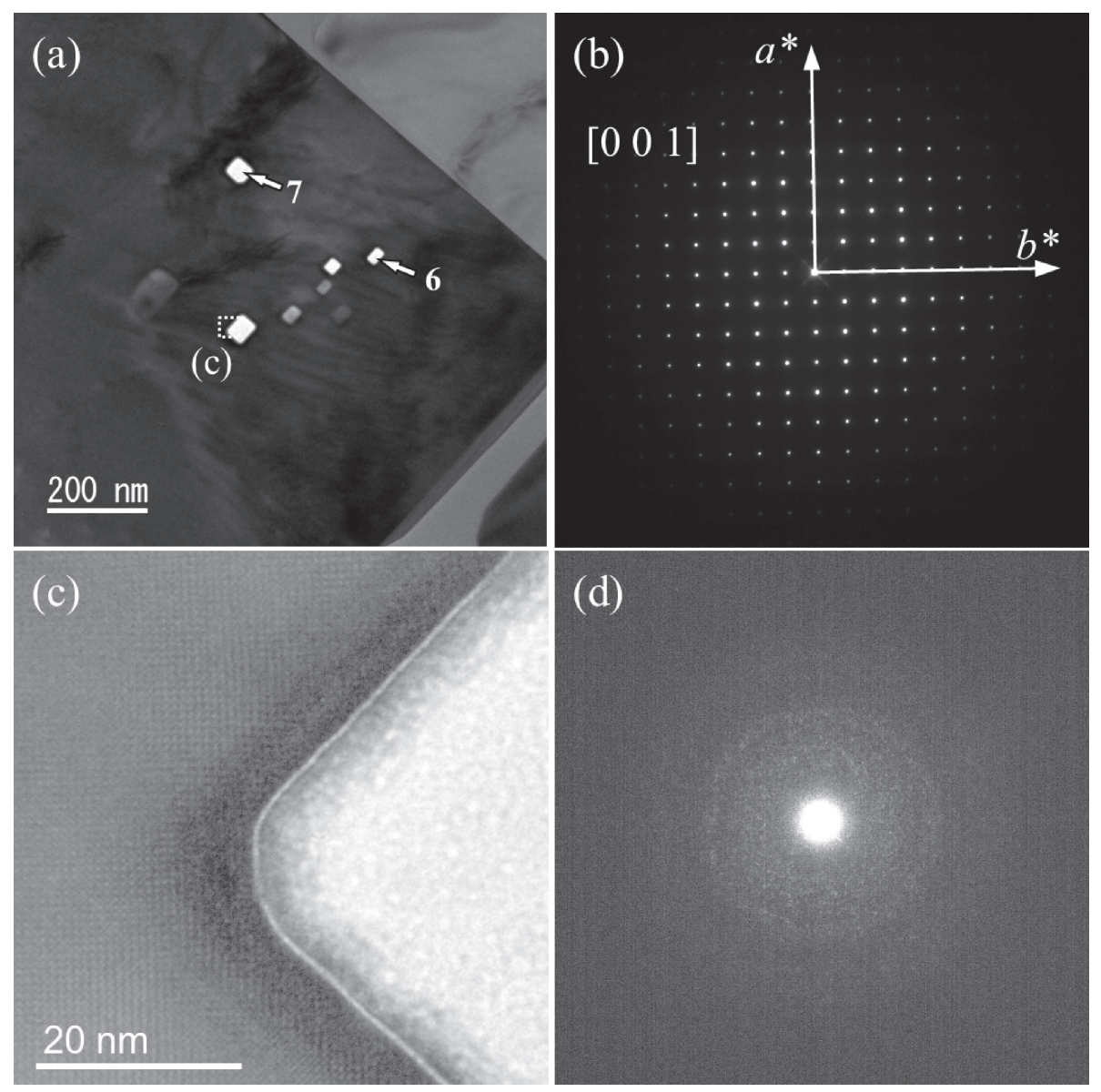

Figure 5. TEM images and diffraction patterns of mullite and its inclusions: (a) BF-TEM image, (b) SAED pattern from (a), (c) enlargement of the area in the dotted rectangle in (a), and (d) nanobeam electron diffraction pattern from the center of the inclusion shown in (c).

Table 2. Chemical compositions by STEM-EDS analyses

\begin{tabular}{|c|c|c|c|c|c|c|c|}
\hline & 1 (Core) & $2(\operatorname{Rim})$ & 3 (Glass) & 4 (Core) & 5 (Rim) & 6 (Inclusion) & 7 (Inclusion) \\
\hline $\mathrm{O}(\mathrm{at} \%)$ & $64.1(9)$ & $64.8(10)$ & $66.8(9)$ & $64.1(9)$ & $64.4(9)$ & $56(3)$ & $56(2)$ \\
\hline $\mathrm{Al}(\mathrm{at} \%)$ & $26.8(7)$ & $23.3(7)$ & $5.8(3)$ & $26.4(8)$ & $23.7(7)$ & $27(3)$ & $20(1)$ \\
\hline $\mathrm{Si}(\mathrm{at} \%)$ & $8.9(3)$ & $11.7(5)$ & $25.7(8)$ & $9.3(4)$ & $11.7(4)$ & $16(2)$ & $20(1)$ \\
\hline K (at\%) & - & - & $1.36(9)$ & - & - & - & - \\
\hline $\mathrm{Fe}(\mathrm{at} \%)$ & $0.22(1)$ & $0.22(4)$ & $0.34(4)$ & $0.22(3)$ & $0.20(3)$ & - & $1.8(3)$ \\
\hline $\mathrm{O}$ & 5 & 5 & 5 & 5 & 5 & 5 & 5 \\
\hline $\mathrm{Al}$ & $2.09(6)$ & $1.80(6)$ & $0.43(2)$ & $2.06(7)$ & $1.84(6)$ & $2.4(2)$ & $1.85(13)$ \\
\hline $\mathrm{Si}$ & $0.69(2)$ & $0.90(4)$ & $1.92(7)$ & $0.73(3)$ & $0.91(4)$ & $1.4(2)$ & $1.85(13)$ \\
\hline $\mathrm{K}$ & - & - & $0.07(1)$ & - & - & - & - \\
\hline $\mathrm{Fe}$ & $0.016(1)$ & $0.017(3)$ & $0.025(3)$ & $0.017(2)$ & $0.016(2)$ & $0.05(3)$ & $0.17(3)$ \\
\hline$x$ value & $0.26(8)$ & $0.00(8)$ & - & $0.22(8)$ & $0.01(8)$ & - & - \\
\hline$(\mathrm{Al}+\mathrm{Fe}) / \mathrm{Si}$ & $3.05(13)$ & $2.01(10)$ & $0.24(1)$ & $2.87(14)$ & $2.04(10)$ & $1.7(3)$ & $1.09(9)$ \\
\hline
\end{tabular}

The compositions were quantified by the $\zeta$ factor method (Watanabe and Williams, 2006).

The analyzed areas are indicated in Figure 4 (dotted circles) and Figure 5 (arrows).

formation on texture. The spatial resolution of EMP (normally several microns in diameter) is not enough for the sub-micrometric texture. Therefore, the variation in previously reported results is to be expected because the analytical regions included mullite, sillimanite, and silicate glass in various proportions. Indeed, our SEM-EDS results show similar variations ( $\sim$ 1.5-3.0 for $\mathrm{Al} / \mathrm{Si}$ ratios $)$. The $\mathrm{K}$ component detected in $\mathrm{Si}$-rich regions in this study appears to be in silicate glass filling between the grains. Matsubara et al. (1998) also reported similar com- 
positional variations. The grains that they interpreted as "siliceous mullite" are probably composed of both sillimanite and 3:2 mullite. The 'heterogeneity in a single crystal' reported by Matsubara et al., (1998) is probably an artifact resulting from analysis of the sub-micrometric core-rim texture by EMP. The 'Al-rich sillimanite' reported by Aramaki (1961) appears to be a similar grain, and his results probably represent an averaged composition. Similarly, Cameron and Ashworth (1972) likely analyzed the averaged composition of the core-rim grains. The slight difference between their results and those of Aramaki (1961) can be interpreted as different mullite/ sillimanite ratios in the analyzed grains.

Aramaki (1961) and Matsubara et al. (1998) reported XRD patterns intermediate between the typical sillimanite and mullite. Aramaki (1961) concluded that the XRD pattern was caused by a phase with the intermediate composition, whereas Matsubara et al. (1998) interpreted it as a mixture of sillimanite and mullite in various proportions. We agree with Matsubara et al. (1998) that the intermediate XRD pattern can be obtained by a mixture of sillimanite and mullite. Indeed, it is difficult to distinguish peaks of mullite and sillimanite, except by using a special XRD system with high angular resolution (e.g., Igami et al., 2017). However, based on our results, we speculate that their mixture comprises grains with the core-rim sillimanite and 3:2 mullite texture.

\section{Formation of the sub-micrometric core-rim textures}

We observed texture of grains with the mullite core and sillimanite rim, everywhere in the present TEM section. Wenk (1983) also reported TEM observations of coexisting mullite and sillimanite with APBs in pelitic inclusions in the Bergell tonalite. However, coexisting mullite and sillimanite in his sample showed a mottled texture. The core-rim texture that we observed thus seems to be characteristic of the Asama sample.

In mullite of the Asama sample, the characteristic glass inclusions (Fig. 5) are morphologically the same as those in mullite synthesized from sillimanite by annealing at high temperatures (e.g., Raterron et al., 1999, 2000; Rahman et al., 2001). Moreover, the glass inclusions are apparently poorer in $\mathrm{K}$ than the interstitial glass (Fig. 4). Therefore, mullite in this sample likely formed from sillimanite at high temperature. The temperature of the transformation from sillimanite to mullite was determined to be $1200{ }^{\circ} \mathrm{C}$ at atmospheric pressure by synchrotron radiation diffraction experiments for annealed sillimanite (Igami et al., 2017). Thus, the temperature of present sample probably reached above $1000{ }^{\circ} \mathrm{C}$ that is previously estimated for pyrometamorphic conditions (Aramaki, 1961). How- ever, the temperature probably has not reached to $1200^{\circ} \mathrm{C}$ because glass inclusions are likely to contain some amount of water which should somewhat depress the melting point. For more precise estimation, impurity (e.g., $\left.\mathrm{Fe}^{3+}, \mathrm{OH}^{-}\right)$and pressure effects $(20-80 \mathrm{MPa}$, Aramaki, 1961) should be considered.

In sillimanite of the grain rims, abundant APBs are displayed in DF-TEM images taken from the $l=$ odd reflections. The presence of $l=$ odd reflections represents the alternation of $\mathrm{AlO}_{4}$ and $\mathrm{SiO}_{4}$ tetrahedra along the $c^{-}$ axis. Thus, these APBs indicate mismatches in $\mathrm{Al} / \mathrm{Si}$ ordered arrangement of tetrahedral sites, with 1/2[001] of displacement vector. It is generally believed that the APBs are formed by transformation from disordered phase to ordered phase. In the present case, the APBs is expected to be formed by the transformation from $\mathrm{Al} / \mathrm{Si}$-disordered sillimanite whose $c$-axial length is half the normal one. However, based on the investigations of the degree of $\mathrm{Al} / \mathrm{Si}$ disorder in stoichiometric sillimanite (Greenwood, 1972; Igami et al., 2018), it is unreasonable to assume that our sample had such a stoichiometric $\mathrm{Al} / \mathrm{Si}$ disordered phase. Instead, mullite also has a disordered $\mathrm{Al} / \mathrm{Si}$ distribution resulting its $\boldsymbol{c}$-axial length is half the size, and it is considerably more stable. Thus, the mismatches of $\mathrm{Al} / \mathrm{Si}$ arrangement (APBs) can be explained by the transformation from mullite $+\mathrm{Si}$-rich melt to sillimanite. Although there is a little probability that the APBs have directly formed by rapid overgrowth of sillimanite, the APBs in sillimanite can be generally interpreted as a residual texture inherited from mullite.

From the above constraints, we conclude that the fibrous minerals observed in this study formed as follows (Fig. 6). First, pelitic sedimentary rocks were trapped or contacted by the magma, and pyrometamorphism formed buchite with aggregates of normal fibrous sillimanite at around $1000{ }^{\circ} \mathrm{C}$ (Aramaki, 1961). Then, the rocks were temporarily heated above $1000{ }^{\circ} \mathrm{C}$ by some kind of igneous activity, transforming the sillimanite to mullite, with incongruent melting forming the fine melt inclusions. Finally, the rocks were cooled to around $1000{ }^{\circ} \mathrm{C}$ again, the outer parts of mullite grains reacted with the surrounding $\mathrm{SiO}_{2}$-rich melt to retrogressively form sillimanite rims with the mismatches of $\mathrm{Al} / \mathrm{Si}$ arrangement, APBs. The rocks were then erupted with volcanic rocks. Some of them might be erupted as xenoliths.

\section{Consideration of phase relation between sillimanite and mullite}

It is generally assumed that sillimanite and mullite do not have a complete solid solution; Cameron (1977) claimed that a sillimanite-mullite miscibility gap exists 
(1)

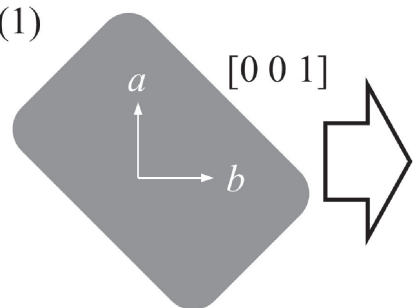

(2)

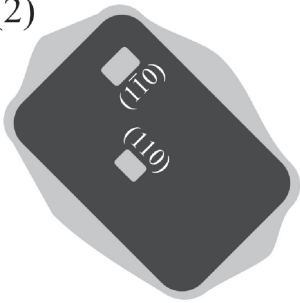

(3)

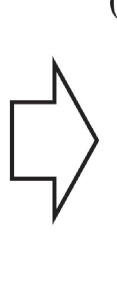

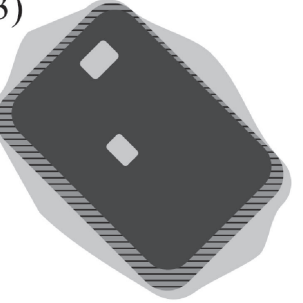

Figure 6. Schematic illustrations of the formation process of mullite-sillimanite aggregates with the corerim texture in the Asama sample. First, aggregates of normal fibrous sillimanite were formed at around $1000{ }^{\circ} \mathrm{C}$ (Stage1). Then, the rocks were temporarily heated above 1000 ${ }^{\circ} \mathrm{C}$ by some kind of igneous activity, transforming the sillimanite to mullite, with incongruent melting forming the fine melt inclusions (Stage 2). Finally, the rocks were cooled to around $1000{ }^{\circ} \mathrm{C}$ again, the outer parts of mullite grains reacted with the surrounding $\mathrm{SiO}_{2}$-rich melt to retrogressively form sillimanite rims with the mismatches of $\mathrm{Al} / \mathrm{Si}$ arrangement, APBs (Stage 3).

when $0.04<x \leq 0.17$ in $\mathrm{Al}_{2}^{\mathrm{VI}}\left(\mathrm{Al}_{2+2 x} \mathrm{Si}_{2-2 x}\right)^{\mathrm{IV}} \mathrm{O}_{10-x}$, based on his comprehensive analyses for various natural and synthetic samples. In contrast, 'Al-rich sillimanite' from Asama volcano reported by Aramaki (1961) is oppose to Cameron (1977), and has been regarded as evidence that a complete solid solution between sillimanite and mullite exists at certain conditions. However, we have shown that the analytical results of Aramaki (1961) can be interpreted as the coexistence of sillimanite and 3:2 mullite, and thus his 'Al-rich sillimanite' at Asama is no longer sufficient as evidence of a solid solution. At conditions around $1200{ }^{\circ} \mathrm{C}$ and $20-80 \mathrm{MPa}$, the compositional gap between sillimanite and 3:2 mullite exists, consistent with the $\mathrm{Al}_{2} \mathrm{O}_{3}-\mathrm{SiO}_{2}$ binary phase diagram of Igami et al. (2017).

\section{ACKNOWLEDGMENTS}

We are grateful to Katsumi Nishikubo for providing the meaningful sample of Asama volcano. We deeply thank Satoshi Matsubara (National Museum of Nature and Science) and Takashi Ishibashi (Masutomi Museum of Geoscience) for providing information about previous studies, and Michihiko Nakamura and Mayumi Mujin (Tohoku University) for providing information on the locality of the sample. We appreciate valuable improvements of this manuscript by Naotaka Tomioka and anonymous reviewer. This work was supported by JSPS KAKENHI Grant Numbers JP15H05695 and JP16H06348 to AM.

\section{SUPPLEMENTARY MATERIAL}

Color version of Figure 1 is available online from https:// doi.org/10.2465/jmps. 180201 .

\section{REFERENCES}

Aramaki, S. (1961) Sillimanite and cordierite from volcanic xenoliths. American Mineralogist, 46, 1154-1165.

Balzar, D. and Ledbetter, H. (1993) Crystal structure and compressibility of 3:2 mullite. American Mineralogist, 78, 1192-1196.

Bowen, N.L. and Greig, U.J. (1924) The system: $\mathrm{Al}_{2} \mathrm{O}_{3} \cdot \mathrm{SiO}_{2}$. Journal of the American Ceramic Society, 7, 238-254.

Cameron, W.E. (1977) Mullite; a substituted alumina. American Mineralogist, 62, 747-755.

Cameron, W.E. and Ashworth, J.R. (1972) Fibrolite and its relationship to sillimanite. Nature, 235, 134-136.

Grapes, R. (2010) Introduction. In Pyrometamorphism (Grapes R. Ed.). Springer, Berlin, 1-9.

Greenwood, H.J. (1972) AlIV-SiIV disorder in sillimanite and its effect on phase relations of the aluminum silicate minerals. Geological Society of America Memoirs, 132, 553-572.

Igami, Y., Ohi, S. and Miyake, A. (2017) Sillimanite-mullite transformation observed in synchrotron X-ray diffraction experiments. Journal of the American Ceramic Society, 100, 49284937.

Igami, Y., Kuribayashi, T. and Miyake, A. (2018) Determination of $\mathrm{Al} / \mathrm{Si}$ order in sillimanite by high angular resolution electron channeling X-ray spectroscopy, and implications for determining peak temperatures of sillimanite. American Mineralogist, 103, 944-951.

Matsubara, S., Miyawakai, R., Tiba, T. and Kato, A. (1998) Mullite in accidental fragments in recent ejecta from Asama Volcano, Japan. Abstracts with program 1997 Annual Meeting, The Japanese Association of Mineralogists, Petrologists and Economic Geologists. The Japanese Association of Mineralogists, Petrologists and Economic Geologists, Sendai, B-4.

Raterron, P., Carpenter, M. and Doukhan, J.C. (1999) Sillimanite mullitization: ATEM investigation and point defect model. Phase Transitions: A Multinational Journal, 68, 481-500.

Raterron, P., Carpenter, M. and Doukhan, J.C. (2000) ATEM investigation of experimentally annealed sillimanite: new constraints for the $\mathrm{SiO}_{2}-\mathrm{Al}_{2} \mathrm{O}_{3}$ join. Mineralogical Magazine, 64, 247-254.

Rahman, S., Feustel, U. and Freimann, S. (2001) Structure description of the thermic phase transformation sillimanite-mullite. 
Journal of the European Ceramic Society, 21, 2471-2478.

Watanabe, M. and Williams, D.B. (2006) The quantitative analysis of thin specimens: a review of progress from the Cliff-Lorimer to the new $\zeta$-factor methods. Journal of Microscopy, 221, 89-109

Wenk, H.R. (1983) Mullite-sillimanite intergrowth from pelitic inclusions in Bergell tonalite. Neues Jahrbuch fur MineralogieAbhandlungen, 146, 1-14.
Winter, J.K. and Ghose, S. (1979) Thermal expansion and hightemperature crystal chemistry of the $\mathrm{Al}_{2} \mathrm{SiO}_{5}$ polymorphs. American Mineralogist, 64, 573-586.

Manuscript received February 1, 2018

Manuscript accepted May 30, 2018

Manuscript handled by Takashi Mikouchi 